\title{
Effects of chitosan-tomato plant extract edible coatings on the quality and shelf life of chicken fillets during refrigerated storage
}

\author{
Saul RUÍZ-CRUZ ${ }^{1 *}$, Carla Cecilia VALENZUELA-LÓPEZ1, Sarai CHAPARRO-HERNÁNDEZ1,
} José de Jesús ORNELAS-PAZ², Carmen Lizette DEL TORO-SÁNCHEZ ${ }^{3}$, Enrique MÁRQUEZ-RÍOS ${ }^{3}$, Marco Antonio LÓPEZ-MATA ${ }^{4}$, Víctor Manuel OCAÑO-HIGUERA ${ }^{5}$, Santiago VALDEZ-HURTADO ${ }^{6}$

\begin{abstract}
The aim of this study was to evaluate the effects of chitosan-tomato plant extract (C-TPE) edible coating (EC) applications on the physicochemical, microbiological, sensory and antioxidant capacity of chicken during storage. Edible coatings prepared with chitosan $1 \%$, acetic acid $1 \%$, glycerol and TPE $(0.1$ and $0.3 \%)$ were tested. The slices were submerged for 1 minute in different treatments (T1: C 1\%; T2: C 1\% + TPE 0.1\%; T3: C 1\% + TPE 0.3\%; T4: control) and stored at $4{ }^{\circ} \mathrm{C}$. At the end of the storage period, the treatments exhibited the greatest physicochemical and microbiological effects in the slices, reducing the microbial population relative to the control. The T2 treatment exhibited the highest antioxidant capacity, total phenolic content and overall acceptance. The results demonstrate that the application of $\mathrm{C}$ with the addition of a natural extract, such as those from the tomato plant, can be an alternative method for preserving chicken meat.
\end{abstract}

Keywords: chitosan; meat products; quality; by-products.

Practical Application: The use of edible coatings made from chitosan-tomato plant extract could be an alternative method for preserving the quality and increasing the shelf life of chicken.

\section{Introduction}

Meat is a popular food around the world with increasing consumption, and chicken meat is one of the most popular because is a nutritious food and its low-fat content. To satisfy the consumer demand the export rates have increased considerably. Because chicken meat is highly perishable and its shelf life is relatively short even in refrigeration storage, the food industry must apply modern preservation methods to extend its shelf life considering the rapid loss of quality and freshness it's due to the biochemical and microbial mechanisms (Boziaris et al., 2011; Mantilla et al., 2011; Kapetanakou et al., 2014). Edible coatings (ECs) have been used as an alternative method to improve the quality and extend the shelf life of fruit, vegetables, and food of animal origin (Suseno et al., 2014; Wu, 2014). They are classified according to their origin as proteins, lipids or polysaccharides (Khanafari et al, 2008; Sánchez-Ortega et al., 2014). Chitosan, which is derived from the deacetylation of chitin, is the most widely used polymer in EC production because of its broad applicability and characteristics, including its ability to form a film and non-toxic property (Mirabella et al., 2014; Suseno et al., 2014). Chitosan edible films provide some characteristics that help to preserve the freshness in meat; additional, these types of films present some antioxidant activity and act like antimicrobial agents against pathogens and spoilage bacteria in foods (López-Mata et al., 2015). The antimicrobial and antioxidant compounds in edible coatings address many of the health and environmental concerns of consumers (Cao et al., 2013; Qin et al., 2013). Nevertheless, despite of these properties of chitosan edible films, some plant extracts have been added because their properties. Tomato plant (leave and steem) represent an agro-industrial byproduct because is discarded after harvesting, however, it possesses bioactive substances with interesting properties (Silva-Beltrán et al., 2015). As bioactive agents incorporated into films, plant extracts, has received attention due to their phenolic content and high antioxidant capacity, which can improve food safety and quality (Huang et al., 2014).

The addition of natural extracts to ECs seeks to potentiate the effects of these extracts on the conservation of food by exploiting the properties of these extracts against bacteria and as antioxidants (Soultos et al., 2008). The aim of the present study was to evaluate the effects of chitosan-based ECs with tomato plant extract on the physicochemical, microbiological, sensory and antioxidant properties of chicken during refrigerated storage changes. 


\section{Materials and methods}

\subsection{Reagents}

Potassium persulfate, 2, 2-azino-bis (3-ethylbenzthiazoline-6sulfonic acid) diammonium salt (ABTS), 2, 2-diphenyl-1 picrylhydrazyl (DPPH), 6-hydroxy-2, 5, 7, 8-tetramethylchroman-2-carboxylic acid (Trolox), and gallic acid were purchased from Sigma-Aldrich (St. Louis, MO, USA). Folin-Ciocalteu reagent, sodium carbonate, hydrochloric acid, hydrogen peroxide $3 \%$, acetic acid, red-violet bile agar, trypticase soy agar, phosphate buffer and sodium chloride were obtained from JT Baker (Baker-Mallinckrodt, México). Sodium hydroxide was purchased from Merck (Merck-Darmstadt, Germany), and glycerol was purchased from HYCEL (Zapopan, Jalisco).

\subsection{Raw material}

Chicken fillets were obtained from local distributors in Cd. Obregon, Sonora. The samples were placed in a sealed cooler with a layer of ice between the samples and transported to the Laboratory of Sanitary Microbiology and Food Safety at the Instituto Tecnológico de Sonora, where they were stored for further analysis.

\subsection{Chitosan}

The chitosan was obtained by thermo-alkaline deacetylation of chitin. $1 \mathrm{~g}$ of chitin was homogenized with $15 \mathrm{~mL}$ of $50 \%$ w/v NaOH at $95^{\circ} \mathrm{C}$ for $2 \mathrm{~h}$ (Khanafari et al., 2008). The degree of acetylation of chitosan used in this study was 34\% with an average molecular weight of $128 \mathrm{kDa}$ as previously described by López-Mata et al. (2015).

\subsection{Plant material}

Residues of tomato plants (Lycopersicon esculentum) of the Pitenza variety were used in the current study and were obtained from greenhouses in the Yaqui Valley in Sonora, México. Twenty sample fresh plants were collected and were washed with distilled water. The plants were dried at $45^{\circ} \mathrm{C}$ by $24 \mathrm{~h}$, later were pulverized.

\subsection{Extract preparation}

The tomato plant extracts were obtained using methods described by Silva-Beltrán et al. (2015). A $35 \mathrm{~g}$ of dried sample was mixed with a solution of ethanol and 5\% acetic acid (95:5 ratio) and macerated in constant stirring for $72 \mathrm{~h}$ in complete darkness at room temperature. The samples were filtered and concentrate by evaporation using a rotatory evaporator (Buchi Rotavapor R-200). Finally, the extract was lyophilized for 48 h (Freeze zone 4.5, Labconco), and the dried extracts were maintained at $-20{ }^{\circ} \mathrm{C}$ for subsequent analysis.

\subsection{Preparation and application of EC}

The emulsions were prepared by dissolving $1 \%$ chitosan (C 1\%) in $1 \%$ acetic acid and glycerol as a plasticizer. Later, tomato plant extracts (TPE) at different concentrations was added. The solution was homogenized at 15,500 rpm (López-Mata et al., 2013) until homogenization was complete. Finally, raw chicken slices were immersed in this solution for one min and allowed to dry after immersion and before storage. Four treatments were prepared: T1 (C 1\%), T2 (C 1\% + TPE 0.1\%), T3 (C 1\% + TPE 0.3\%) and T4 (control). The control was the chicken slice with no edible film treatment.

\subsection{Evaluation of quality and shelf life}

The coated chicken samples were stored in plastic trays with food grade polyethylene at $4{ }^{\circ} \mathrm{C}$ for 16 days. Samples were taken on days $0,1,4,8,12$ and 16 for the physicochemical, microbiological, sensory and antioxidant analyses.

\subsection{Sensory evaluation}

Ten semi-trained panelists scored the samples for odor, flavor, color, texture and overall acceptability on each day of storage. A nine-point hedonic scale ( $9=$ extremely like; $8=$ like it very much, 7 = like it moderately; $6=$ like it slightly, $5=\mathrm{I}$ do not like or dislike, 4 = dislike a little; 3 = dislike moderately, 2 = dislike very much $1=$ extremely dislike) was used to classify the samples. The score of each sample was determined by calculating the mean value. A score of 5 or below was considered to be unsalable. By the sensory evaluation the chicken slices of the different treatments were cooked previously.

\subsection{Physicochemical analysis}

The muscle $\mathrm{pH}$ was determined based on methods described by the AOAC (Association of Official Analytical Chemists, 1995). Ten $\mathrm{g}$ of samples were mixed with $50 \mathrm{~mL}$ of distilled water and the $\mathrm{pH}$ was measured using a digital $\mathrm{pH}$ meter (HANNA model 213, Woonsocket, USA).

For the color measurement, three chicken slices of each treatment were chosen, from which five mediations was taken. The color of chicken was measured by tri-stimulus colorimetry using a system with a colorimeter (X-rite model SP6, Michigan, USA). Color coordinates for degree of lightness (L), redness/greenness $(+\mathrm{a} /-\mathrm{a})$, and yellowness/ blueness $(+\mathrm{b} /-\mathrm{b})$ were obtained.

The exudate loss (EL) was determined by measuring the weight before and after a certain period according to each sampling day; the results were expressed as a percentage (\%).

The water retention capacity (WRC) was determined in the raw samples using a method described by Zhang et al. (1995) with modifications. The meat sample ( $5 \mathrm{~g})$ was finely minced, followed by the addition of $8 \mathrm{~mL}$ of $\mathrm{NaCl}(0.6 \mathrm{M})$. The meat sample was then stirred $(1 \mathrm{~min})$ and placed in an ice bath for $30 \mathrm{~min}$ and centrifuged at $11,500 \mathrm{~g}$ for $15 \mathrm{~min}$ at $4{ }^{\circ} \mathrm{C}$, and the supernatant was recovered. The WRC of the cooked samples was determined as follows: the meat samples were weighed, wrapped in aluminum, subjected to a temperature of $165^{\circ} \mathrm{C}$ on an electric grill and cooked to an internal temperature of $70{ }^{\circ} \mathrm{C}(10 \mathrm{~min}$ for each side), as measured using a penetration thermometer (Thermco ${ }^{\circledast}$, Lafayette, NJ). The samples were cooled for $30 \mathrm{~min}$ at room temperature $\left(25^{\circ} \mathrm{C}\right)$, and the final weight was determined. The WRC was expressed as the loss of water with respect to the initial content (\%) in the raw and cooked samples. 
The shear force value (texture) was expressed as the $\mathrm{N}$ of the raw and cooked samples were measured in a texturometer (Food technology corp., Virginia, USA). The samples were cut (30 $\mathrm{mm} \times 10 \mathrm{~mm} \times 10.5 \mathrm{~mm}$ ), and a transverse force in the direction of the muscle fiber was applied

\subsection{Microbiological analysis}

Chicken meet samples (10 g) were homogenized with sterile phosphate buffers $(90 \mathrm{~mL})$ using a stomacher blender (Model 400) for $2 \mathrm{~min}$ at $230 \mathrm{rpm}$. The homogenate was serially diluted by a ten factor. For each dilution, $1 \mathrm{~mL}$ was plated on each medium according to Mexicans Official Norms (NOM). The total microbial count was determined according to the parameters established by NOM-092-SSA1-1994 (México, 1994a) for both aerobic mesophilic and psychrophilic bacteria using the trypticase soy agar (TSA) procedure; the total coliforms were determined by NOM-113-SSA1-1994 (México, 1994b) in red-violet bile agar.

\subsection{Antioxidant capacity}

For the extract preparation, $10 \mathrm{~g}$ of the sample was homogenized, and a volume equivalent of $10 \%$ phosphate buffer (pH 7) was added. The mixture was centrifuged at 12,000 rpm for $60 \mathrm{~min}$ at $4{ }^{\circ} \mathrm{C}$. The supernatant was used to estimate the ABTS, DPPH and total phenolics.

The ABTS assay was conducted using methods described by Erel (2004) with some modifications. ABTS radical cations were generated in a mixture of $5 \mathrm{~mL}$ of a $7 \mathrm{mmol}$ ABTS solution and $88 \mu \mathrm{L}$ of a $0.139 \mathrm{mmol} \mathrm{K}_{2} \mathrm{~S}_{2} \mathrm{O}_{8}$ solution. The extracts were diluted with absolute ethanol. Then, $1.98 \mathrm{~mL}$ of the adjusted solution was reacted with $15 \mu \mathrm{L}$ of the supernatant, centrifuged at $13,000 \mathrm{rpm}$ for $5 \mathrm{~min}$ at $4{ }^{\circ} \mathrm{C}$ and left to rest for $7 \mathrm{~min}$. The absorbance was measured at $750 \mathrm{~nm}$ using a microplate reader (Bio-rad iMark 168-1135, Tokyo Japan). The results were expressed as $\mu \mathrm{mol}$ Trolox eq/g of meat.

The DPPH assay was conducted using methods described by Qwele et al. (2013) with some modifications. To prepare the radical, DPPH was dissolved in $100 \mathrm{~mL}$ of methanol. A volume of $1 \mathrm{~mL}$ of the adjusted solution, $200 \mu \mathrm{L}$ of the supernatant and $800 \mu \mathrm{L}$ of distilled water were mixed and centrifuged at $13,000 \mathrm{rpm}$ for $5 \mathrm{~min}$ at $4{ }^{\circ} \mathrm{C}$ and left to rest at room temperature for $30 \mathrm{~min}$. The absorbance was measured at $490 \mathrm{~nm}$ using a microplate reader (Bio-rad iMark 168-1135, Tokyo Japan). The results were expressed as $\mu \mathrm{mol}$ Trolox eq/g of meat.

The concentration of the total phenol content was determined according to the method described by Qwele et al. (2013), with modifications. For the reaction mixture, we added $66 \mu \mathrm{L}$ of the supernatant, $133 \mu \mathrm{L}$ of Folin Ciocalteau, followed by the addition of $2 \mathrm{~mL}$ of sodium carbonate. The mixture was stirred manually and then incubated at room temperature for $1 \mathrm{~h}$ and filtered. The absorbance was read at $750 \mathrm{~nm}$ using a microplate reader (Bio-rad iMark 168-1135, Tokyo Japan). The results were expressed as $\mathrm{mg}$ of $\mathrm{GAE} / \mathrm{g}$ of meat.

\subsection{Experimental design and statistical analysis}

The experiment was conducted two times, and each determination was performed in triplicate. The statistical tests were performed using Statgraphics Plus v. 5.1. The experiment was performed by applying a randomized complete block design in which the sampling days were considered blocks and the applied treatments were considered factors. The Tukey-Kramer test was used to determine the differences between the treatments. The results were expressed as the mean values $\pm S D$, and the level of significance was $\mathrm{p}<0.05$.

\section{Results and discussion}

\subsection{Sensory evaluation}

The $\mathrm{T} 2$ treatment presented the highest value for the evaluated attributes (odor, color, taste, texture and general acceptability) in both products and was slightly higher than T3, although this difference was not significant $(p>0.05)$ (Table 1), except on the 16th day of storage. On day 0 , the odor and taste were satisfactory. The addition of the edible coating was pleasant for the panelists. The overall acceptability value of the control on day 4 was 4.9 and on day 8 this samples were inedible. The coated chicken exhibited a fresh odor over a long period of time. The products treated with the edible coating with added extracts remained edible for all 16 days of storage. This indicates that the treatments were effective in maintaining the quality of chicken meat with respect to control. Moreover, the punctuation indicates that the addition of extracts at lower concentrations did not negatively affect the sensory properties and instead significantly improved some of these properties throughout the storage period. This could have been due to the antioxidant properties of the tomato extract, which have a significant effect on color. In this study, the T2 treatment was the favorite of the panelists because it produced a slightly dark color, natural taste, odor and pleasant texture, whereas the other parameters had lower punctuations as higher concentrations were added, with taste being the most sensitive attribute (Selani et al., 2011; Huang et al., 2012; Petrou et al., 2012; Radha-Krishnan et al., 2014; Qi et al, 2015).

\subsection{Physicochemical analysis}

The $\mathrm{pH}$ of the meat is used to evaluate the durability, quality and suitability of various types of processing. The $\mathrm{pH}$ values of the chicken slices with edible coating with and without tomato plant extract are shown in Table 2. The initial values ranged from 5.9 to 6.36 , showing a slight decrease on the 1 st day. The values increased as the storage time progressed. The peak $\mathrm{pH}$ values were $6.48,6.18$ and 6.17 for the T1, T2 and T3 treatments, respectively, whereas $\mathrm{T} 4$ (control) reached a pH of $6.72(\mathrm{p}<0.05)$. Radha-Krishnan et al. (2014) observed the same behavior in chicken slices with spicy extracts, with the values ranging from 5.63 to 5.1-6.6, and the control showed the highest values. In addition, Olaimat \& Holley (2015) reported the same behavior but with lower values following the application of edible coating with carragenin and chitosan, mustard extract or a combinations of these. The decrease in the $\mathrm{pH}$ values may have been due to the production of lactic acid in the muscle via anaerobic glycolysis 
Table 1. Effects of chitosan-tomato plant extract coatings on the sensory evaluation of chicken during refrigerated storage.

\begin{tabular}{|c|c|c|c|c|c|c|c|}
\hline \multirow{2}{*}{ Parameter } & \multicolumn{7}{|c|}{ Storage time (days) } \\
\hline & Treatment & 0 & 1 & 4 & 8 & 12 & 16 \\
\hline \multirow{2}{*}{ Odor } & $\mathrm{T} 2$ & $8.8 \pm 0.42^{\mathrm{a}}$ & $8.9 \pm 0.31^{\mathrm{a}}$ & $8.8 \pm 0.42^{\mathrm{a}}$ & $8.4 \pm 0.51^{\mathrm{a}}$ & $7.6 \pm 0.51^{\mathrm{a}}$ & $7.1 \pm 0.73^{\mathrm{a}}$ \\
\hline & $\mathrm{T} 4$ & $8.9 \pm 0.31^{\mathrm{a}}$ & $8.8 \pm 0.42^{\mathrm{a}}$ & $4.6 \pm 0.36^{\mathrm{b}}$ & NE & NE & NE \\
\hline \multirow[t]{2}{*}{ Flavor } & $\mathrm{T} 1$ & $8.3 \pm 0.82^{\mathrm{a}}$ & $8.3 \pm 0.82^{\mathrm{a}}$ & $7.9 \pm 0.56^{\mathrm{a}, \mathrm{b}}$ & $6.6 \pm 0.51^{\mathrm{b}}$ & $6.4 \pm 0.51^{\mathrm{b}}$ & $4.9 \pm 0.99^{\mathrm{b}}$ \\
\hline & $\mathrm{T} 4$ & $8.3 \pm 0.82^{\mathrm{a}}$ & $8.1 \pm 0.73^{\mathrm{a}}$ & $4.8 \pm 0.32^{c}$ & NE & NE & NE \\
\hline \multirow[t]{3}{*}{ Color } & $\mathrm{T} 1$ & $8.5 \pm 0.84^{\mathrm{a}}$ & $8.5 \pm 0.84^{\mathrm{a}}$ & $7.9 \pm 0.56^{\mathrm{b}}$ & $7.7 \pm 0.48^{\mathrm{b}}$ & $7.6 \pm 0.51^{\mathrm{a}}$ & $6.6 \pm 0.84^{\mathrm{b}}$ \\
\hline & $\mathrm{T} 2$ & $8.7 \pm 0.48^{\mathrm{a}}$ & $8.9 \pm 0.31^{\mathrm{a}}$ & $9.0 \pm 0.0^{\mathrm{a}}$ & $8.4 \pm 0.51^{\mathrm{a}}$ & $7.9 \pm 0.31^{\mathrm{a}}$ & $7.3 \pm 0.48^{\mathrm{a}}$ \\
\hline & $\mathrm{T} 3$ & $8.5 \pm 0.84^{\mathrm{a}}$ & $8.5 \pm 0.84^{\mathrm{a}}$ & $7.6 \pm 0.69^{\mathrm{b}}$ & $7.6 \pm 0.51^{\mathrm{b}}$ & $6.8 \pm 0.78^{\mathrm{b}}$ & $6.0 \pm 0.66^{c}$ \\
\hline \multirow{2}{*}{ Texture } & $\mathrm{T} 3$ & $8.5 \pm 0.84^{\mathrm{a}}$ & $8.5 \pm 0.70^{\mathrm{a}}$ & $7.7 \pm 0.48^{\mathrm{a}}$ & $7.9 \pm 0.31^{\mathrm{a}}$ & $7.8 \pm 0.63^{\mathrm{a}}$ & $4.6 \pm 1.17^{\mathrm{b}}$ \\
\hline & $\mathrm{T} 4$ & $8.7 \pm 0.42^{\mathrm{a}}$ & $8.5 \pm 0.52^{\mathrm{a}}$ & $4.6 \pm 0.26^{\mathrm{b}}$ & NE & NE & NE \\
\hline \multirow[t]{4}{*}{ Overall acceptability } & $\mathrm{T} 1$ & $8.4 \pm 0.51^{\mathrm{a}}$ & $8.4 \pm 0.51^{\mathrm{a}}$ & $8.0 \pm 0.0^{\mathrm{a}}$ & $7.3 \pm 0.48^{\mathrm{a}}$ & $6.8 \pm 0.42^{\mathrm{b}}$ & $5.4 \pm 0.69^{b}$ \\
\hline & $\mathrm{T} 2$ & $8.5 \pm 0.52^{\mathrm{a}}$ & $8.8 \pm 0.42^{\mathrm{a}}$ & $8.2 \pm 0.42^{\mathrm{a}}$ & $7.9 \pm 0.31^{\mathrm{b}}$ & $7.4 \pm 0.51^{\mathrm{a}}$ & $6.9 \pm 0.31^{\mathrm{a}}$ \\
\hline & T3 & $8.3 \pm 0.67^{\mathrm{a}}$ & $8.3 \pm 0.48^{\mathrm{a}}$ & $7.6 \pm 0.51^{\mathrm{b}}$ & $7.3 \pm 0.48^{\mathrm{a}}$ & $6.5 \pm 0.52^{\mathrm{b}}$ & $5.6 \pm 0.51^{\mathrm{b}}$ \\
\hline & $\mathrm{T} 4$ & $8.5 \pm 0.42^{\mathrm{a}}$ & $8.3 \pm 0.48^{\mathrm{a}}$ & $4.9 \pm 0.12^{c}$ & NE & NE & NE \\
\hline
\end{tabular}

Different letters in the same column indicate significant differences $(\mathrm{p}<0.05)$ among treatments. NE: Not evaluated.

Table 2. Effects of chitosan-tomato plant extract coatings on the physicochemical parameters of chicken during refrigerated storage.

\begin{tabular}{|c|c|c|c|c|c|c|c|}
\hline \multirow{2}{*}{ Parameter } & \multicolumn{7}{|c|}{ Storage time (days) } \\
\hline & Treatment & 0 & 1 & 4 & 8 & 12 & 16 \\
\hline \multirow[t]{3}{*}{$\mathrm{pH}$} & $\mathrm{T} 1$ & $5.94 \pm 0.08^{\mathrm{a}}$ & $5.86 \pm 0.09^{\mathrm{a}}$ & $6.09 \pm 0.04^{\mathrm{a}}$ & $6.31 \pm 0.03^{\mathrm{a}}$ & $6.38 \pm 0.01^{\mathrm{a}}$ & $6.48 \pm 0.01^{\mathrm{a}}$ \\
\hline & $\mathrm{T} 2$ & $5.85 \pm 0.02^{\mathrm{b}}$ & $5.85 \pm 0-05^{\mathrm{a}}$ & $6.01 \pm 0.04^{\mathrm{b}}$ & $6.11 \pm 0.01^{\mathrm{b}}$ & $6.16 \pm 0.05^{\mathrm{b}}$ & $6.18 \pm 0.03^{b}$ \\
\hline & $\mathrm{T} 4$ & $6.36 \pm 0.03^{\mathrm{d}}$ & $6.41 \pm 0.08^{c}$ & $6.72 \pm 0.07^{c}$ & NE & NE & NE \\
\hline \multirow[t]{3}{*}{$\mathrm{L}^{*}$} & $\mathrm{~T} 1$ & $60.80 \pm 1.61^{\mathrm{a}}$ & $55.33 \pm 1.67^{\mathrm{a}}$ & $52.48 \pm 1.17^{\mathrm{a}}$ & $53.53 \pm 1.51^{\mathrm{a}}$ & $52.67 \pm 1.50^{\mathrm{a}}$ & $50.81 \pm 1.16^{\mathrm{a}}$ \\
\hline & $\mathrm{T} 3$ & $58.81 \pm 1.97^{\mathrm{b}}$ & $55.06 \pm 1.97^{\mathrm{a}}$ & $52.59 \pm 1.97^{\mathrm{a}}$ & $53.21 \pm 1.84^{\mathrm{a}}$ & $52.62 \pm 2.25^{\mathrm{a}}$ & $50.41 \pm 1.95^{\mathrm{a}}$ \\
\hline & $\mathrm{T} 4$ & $54.34 \pm 1.86^{c}$ & $52.79 \pm 2.34^{\mathrm{b}}$ & $50.37 \pm 2.28^{b}$ & $\mathrm{NE}$ & $\mathrm{NE}$ & NE \\
\hline \multirow[t]{3}{*}{$a^{*}$} & $\mathrm{~T} 1$ & $0.09 \pm 0.50^{\mathrm{a}}$ & $1.21 \pm 0.79^{\mathrm{a}}$ & $2.61 \pm 1.23^{\mathrm{a}}$ & $2.89 \pm 0.84^{\mathrm{a}}$ & $2.71 \pm 0.91^{\mathrm{ab}}$ & $2.37 \pm 0.51^{\mathrm{a}}$ \\
\hline & $\mathrm{T} 2$ & $1.19 \pm 1.80^{\mathrm{b}}$ & $2.74 \pm 1.80^{\mathrm{b}}$ & $4.19 \pm 1.85^{\mathrm{b}}$ & $4.12 \pm 1.92^{\mathrm{a}}$ & $3.88 \pm 1.66^{\mathrm{b}}$ & $3.10 \pm 1.27^{\mathrm{b}}$ \\
\hline & $\mathrm{T} 3$ & $-0.21 \pm 1.11^{\mathrm{a}}$ & $0.85 \pm 1.03^{\mathrm{a}}$ & $2.12 \pm 1.07^{\mathrm{a}}$ & $1.86 \pm 0.82^{\mathrm{b}}$ & $2.31 \pm 1.20^{\mathrm{a}}$ & $1.80 \pm 1.03^{\mathrm{a}}$ \\
\hline \multirow{2}{*}{$\mathrm{b}^{*}$} & $\mathrm{~T} 3$ & $9.40 \pm 1.49^{\mathrm{a}}$ & $11.22 \pm 1.63^{\mathrm{a}}$ & $11.72 \pm 1.29^{\mathrm{ac}}$ & $12.28 \pm 1.71^{\mathrm{a}}$ & $11.99 \pm 1.37^{\mathrm{a}}$ & $12.16 \pm 1.27^{\mathrm{a}}$ \\
\hline & $\mathrm{T} 4$ & $11.29 \pm 2.93^{b}$ & $12.59 \pm 2.96^{\mathrm{b}}$ & $11.98 \pm 2.77^{c}$ & $\mathrm{NE}$ & $\mathrm{NE}$ & $\mathrm{NE}$ \\
\hline \multirow[t]{4}{*}{ Exudate loss (\%) } & $\mathrm{T} 1$ & $3.38 \pm 0.37^{\mathrm{a}}$ & $3.57 \pm 0.13^{\mathrm{a}}$ & $3.71 \pm 0.24^{\mathrm{a}}$ & $4.10 \pm 0.22^{\mathrm{a}}$ & $4.99 \pm 0.27^{\mathrm{a}}$ & $5.12 \pm 0.17^{\mathrm{a}}$ \\
\hline & $\mathrm{T} 2$ & $1.74 \pm 0.27^{\mathrm{b}}$ & $3.18 \pm 0.21^{\mathrm{b}}$ & $3.68 \pm 0.25^{\mathrm{b}}$ & $3.78 \pm 0.40^{\mathrm{b}}$ & $4.22 \pm 0.32^{\mathrm{b}}$ & $5.66 \pm 0.21^{b}$ \\
\hline & $\mathrm{T} 3$ & $1.86 \pm 0.39^{c}$ & $3.85 \pm 0.33^{c}$ & $4.57 \pm 0.33^{c}$ & $4.50 \pm 0.42^{c}$ & $5.33 \pm 0.27^{c}$ & $5.28 \pm 0.07^{c}$ \\
\hline & $\mathrm{T} 4$ & $3.84 \pm 0.20^{\mathrm{d}}$ & $4.42 \pm 0.26^{\mathrm{d}}$ & $5.35 \pm 0.13^{\mathrm{d}}$ & NE & NE & NE \\
\hline
\end{tabular}

Different letters in the same column indicate significant differences $(\mathrm{p}<0.05)$ among treatments; NE: Not evaluated. 
(Márquez-Ríos et al., 2011); however, the application of the edible chitosan coating can affect the $\mathrm{pH}$ due to its acetic acid content (Ahmed et al., 2017). Moreover, the $\mathrm{pH}$ value increased as the storage time increased due to the growth of proteolytic bacteria, which causes protein degradation and the liberation of nitrogen compounds (Cao et al., 2013).

The $L^{*}$ values are shown in Table 2 . The initial values ranged from 54 to 61 . By the end of the storage period, the values had decreased to $50.81,52.02$ and 50.41 for the T1, T2 and T3 treatments, respectively. The $L^{*}$ values of the control (T4) reached 50.37 on day 4 (at end of the shelf life). The $a^{\star}$ values initially ranged from -0.21 to 1.37 and increased significantly by day 4 to $4.52,4.19,2.61$ and 2.12 for T4, T2, T1 and T3, respectively. By the end of the storage period, the values had decreased to 2.37 (T1), 3.10 (T2) and 1.8 (T3). The initial $b^{*}$ values ranged from 8 to 13 for all treatments and progressively increased by day 8 . By day 16 , the values had decreased to 12.05 (T1), 16.65 (T2) and 12.16 (T3), which were higher than the values observed in the control (11.98). Latou et al. (2014) used edible coatings with the addition of modified atmospheres in chicken and obtained initial $L^{\star}$ values of 59 and 60 . On day 14 , the values increased to 61 and 63 , which were higher than those observed in the control at the end of its shelf life on day $6\left(L^{*}\right.$ value of 56). The initial $a^{*}$ and $b^{\star}$ values were 4 and 5 , respectively, for all of the treatments. The final $a^{\star}$ values were 3.5 and 4 , and the final $b^{*}$ values were 16.1 and 15 . These values were higher than the $a^{\star}$ and $b^{\star}$ values measured in the control (3.3 and 14.5, respectively). Petrou et al. (2012) reported similar $L^{*}$ values with the application of oregano oil, $1.5 \%$ chitosan and the combination in chicken. The initial $L^{*}$ value was 51 for all of the treatments. On day 18 , the values increased to 58, 56 and 52 for the oregano oil, chitosan and combination treatments, respectively; these values exceeded the value measured in the control (50). The initial $a^{\star}$ and $b^{\star}$ values reported by Petrou et al. (2012) (9.1, 8.9 and 11 for $a^{*}$ and 17.9, 16.1 and 15 for $b^{*}$ ) were higher than those obtained in the current study ( 8 and 15 , respectively) and exceeded the $\mathrm{a}^{\star}$ and $\mathrm{b}^{\star}$ values observed in the control (3.3 and 14.5, respectively). The addition of chitosan to the chicken slices increased the $\mathrm{L}^{\star}$ values, which are directly related to muscular protein decomposition. Therefore, the rate of fresh meat discoloration is related to the pigment oxidation rate, oxygen consumption and system efficiency of meta-myoglobin reduction (MacDougall, 1982; Latou et al., 2014). Similarly, the increase in the $a^{*}$ values (redness) could be related to the myoglobin content inside the chicken breast (Latou et al., 2014). The addition of chitosan increased the $b^{*}$ values (yellowness), suggesting the natural chitosan color affected the surface color of this meat product.

Table 2 shows the effects of treatment on the exudate loss, where the initial values were $3.38,1.74,1.86$ and 3.84 for the $\mathrm{T} 1, \mathrm{~T} 2, \mathrm{~T} 3$ and T4 treatments, respectively. These results clearly indicate increases that reached 5.12 (T1), 5.66 (T2) and 5.28 (T3) by the end of the storage period, whereas controls reached a value of 5.35. Young et al. (2004) evaluated the effects of feed supplemented with creatine and pyruvate. In this study, the authors obtained values ranging from $4-20 \%$. The values obtained for the treatments and the control differed such that supplementation significantly decreased the values. In contrast, these changes are a practical indicator of myofibrillar protein structure changes, where decreases indicate protein denaturalization. The liberation of drops from the muscle seems to be independent of the contraction state after rigor instauration. This finding could be due to the filamental space and cellular membrane changes that cause water liberation in the extracellular space (Young et al., 2004).

Figure 1 shows the effects of the different treatments on the WRC of fresh (Figure 1a) and cooked (Figure 1b) chicken slices, where the initial values of the fresh slices were 94.55, 91.2, 91.09 and 90.58 for T4, T1 T2 and T3, respectively. The values decreased during the storage period $(81.35,86.78$ and 90.62 for $\mathrm{T} 1, \mathrm{~T} 2$ and T3, respectively); the treatment values were higher than the control value (77.42). Qin et al. (2015) evaluated the effects of the application of L-arginine and a soluble salt gel with meat proteins on the WRC of chicken breast. The values ranged from $80-95 \%$, and higher concentrations resulted in better WRC. These results were similar to those observed in the current study: as time advanced, the extract treatments (T2 and T3) exhibited better WRC. The behavior of the cooked chicken throughout the storage period was variable between treatments. The initial values were $79.63,73.81,70.21$ and 75.87 for the T1, T2, T3 and T4 treatments, respectively. The T3 treatment exhibited better WRC on day 8 (82.34), followed by T2 (76.56) and T1 (69.18), and the control reached 80.08 on the final day of shelf life day (day 4). At the end of the storage period the WRC values of

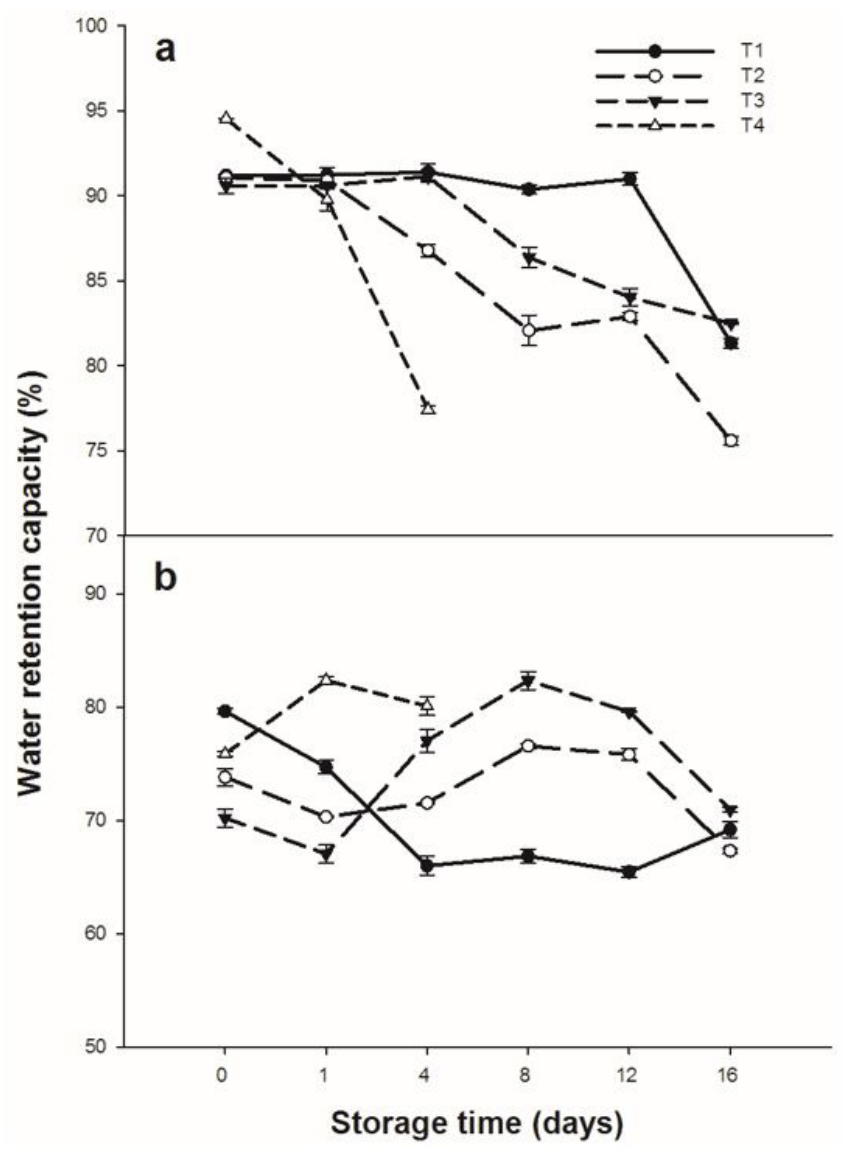

Figure 1. Effects of chitosan-tomato plant extract coatings on WRC in raw (a) and cooked (b) chicken during refrigerated storage. 
the treatments reached 66.84 (T1), 67.30 (T2) and 70.96 (T3); T3 exhibited the best WRC. Kiliç et al. (2014) evaluated the effects of encapsulated phosphates in cooked chicken meat and obtained values ranging from $82-92 \%$. The values obtained using encapsulated phosphates were higher than those reported in the current study. These differences could be attributed to the meat preparation methods used for the analysis (they used meat ground); however, the values decreased with some of the treatments. This behavior could be due to processes related to the WRC in meat, such as protein denaturalization and cellular structure disintegration during cooking (Bertram et al., 2003). It has been suggested that $\mathrm{pH}$ differences in the meat protein isoelectric point (higher values avoid denaturalization) can increase the WRC (Kiliç et al., 2014), but the type of fiber, species, oxidative stability, cooking and temperature could also be related factors (Kristensen \& Purslow, 2001; Kiliç et al., 2014).

The texture of the fresh chicken breast (Figure 2a) decreased on day 4 and then increased until the final day of storage. T1 and T2 $(12.11$ and $10.56 \mathrm{~N})$ yielded the highest results, and T3 yielded the lowest $(8.68 \mathrm{~N})$; the textures differed significantly ( $p>0.05$ ) between treatments. In contrast, cooked slices (Figure $2 \mathrm{~b}$ ) presented a variable behavior such that the values decreased on day 1 with the T1, T2 and T4 treatments and then

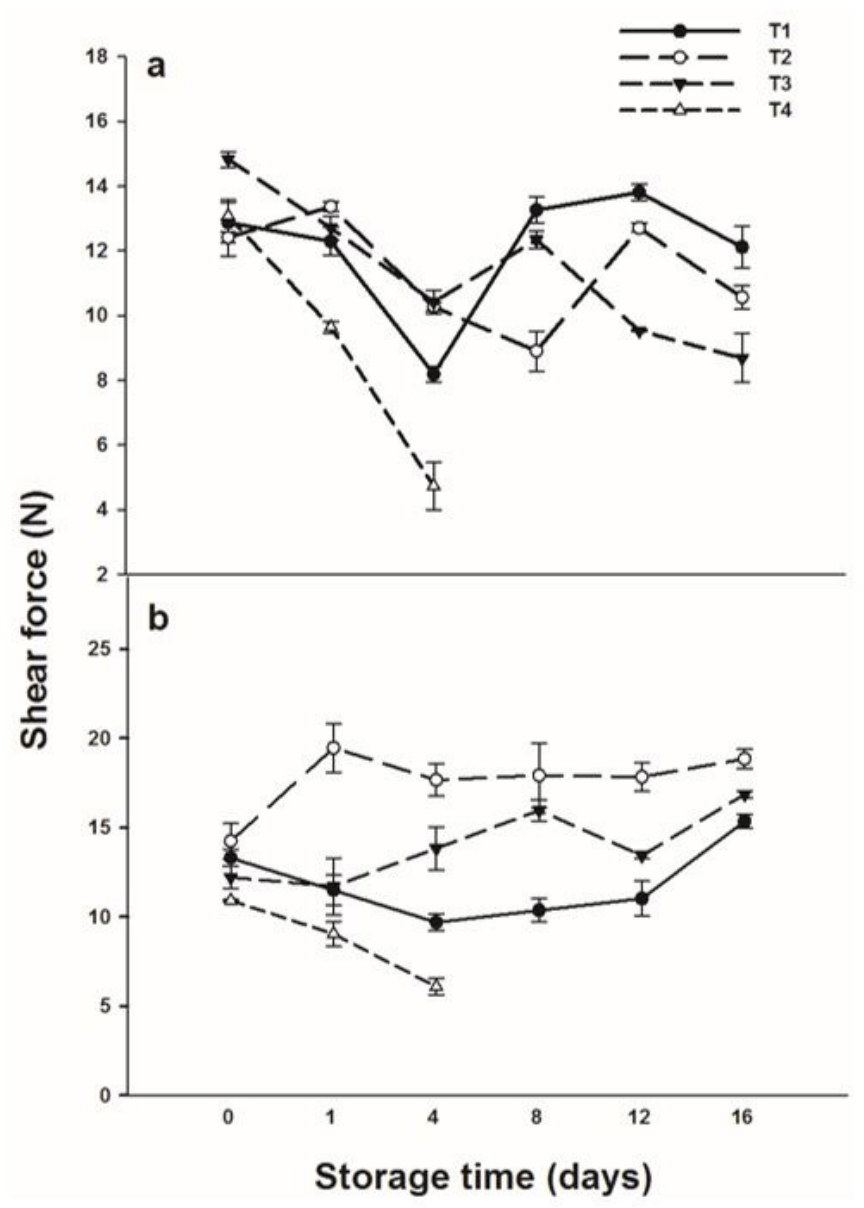

Figure 2. Effects of chitosan-tomato plant extract coatings on texture in raw (a) and cooked (b) chicken during refrigerated storage. progressively increased until day 16 (final storage day), reaching a maximum of $15.35,18.84$ and 16.85 for the T1, T2 and T3 treatments, respectively. Rodríguez-Calleja et al. (2012) evaluated the application of antimicrobial edible coatings on chicken quality using hydrostatic high pressure and did not observe any significant differences between treatments in the initial values, which suggested this behavior is related to the protein system, temperature, pressure and duration of storage. Soysal et al. (2015) evaluated the effects of antimicrobial packing on chicken strips during storage and obtained values ranging from $2.7 \mathrm{~N}$ to $2.4 \mathrm{~N}$. The authors concluded that over long storage periods, the use of antimicrobial packing does not have an undesirable effect on the chicken breast texture. The values reported in their study were lower than those reported in the current study. Treatment 3 produced lower values in both presentations (fresh and cooked chicken), followed by T2 and T1. These results could be explained by decreases in the gelation capacity caused by extract concentration increases in the chitosan emulsion that may affect the adherence of the edible coating in food. Similarly, changes in these values may be due to the degree of water drop loss in the meat during storage.

\subsection{Microbiological analysis}

The different treatments reduced the population of aerobic mesophilic bacteria by 1 Log CFU/g (Figure 3a); the T3 treatment produced the best results. In contrast, the effect (Figure $3 \mathrm{~b}$ ) decreased the total coliform population in the T2 and T3 treatments on day 1 and increased the population on day 4 , maintaining growth over time and reducing by 1 Log CFU/g. These results are similar to those reported by Higueras et al. (2013), who evaluated the effects of an edible coating in fresh chicken over an 8-day period. This study observed the same behavior observed in the current study and the population of aerobic mesophilic bacteria reached 3 and $2 \mathrm{Log} \mathrm{CFU} / \mathrm{g}$ in the total coliforms with the treatments applied. These results indicated a positive effect such that both populations were reduced by 3 Log CFU/g. In contrast, Olaimat \& Holley (2015) evaluated the effects of an edible coating of chitosan with mustard extract applied to fresh chicken breast and observed that the aerobic mesophilic bacteria population was reduced by $1 \mathrm{Log}$ CFU/g during the storage period. The positive effects increased with longer exposure times. Fernández-Pan et al. (2014) evaluated the antimicrobial effects of edible coating applied to chicken over a 13-day period and observed that the natural extract produced better results in chicken, reducing the bacterial population by $1 \mathrm{Log} \mathrm{CFU} / \mathrm{g}$. The positive effects increased with higher extract concentrations, thus indicating the importance of concentration on the antimicrobial effect.

For the psycrophilic bacteria (Figure 3c), the initial values were 1.9 Log CFU/g in the treated samples, and the control had a higher value of $2.4 \mathrm{Log} \mathrm{CFU} / \mathrm{g}$. On day 1 , the values decreased and then progressively increased during storage, showing a reduction by $1 \mathrm{Log} \mathrm{CFU} / \mathrm{g}$ compared to the control. Higueras et al. (2013) evaluated the effects of chitosan edible coating with an alcoholic compound in chicken and observed growth starting on day 2 and a $4 \mathrm{Log} \mathrm{CFU} / \mathrm{g}$ reduction. The authors suggested that the preservative effects of the edible coating could be due 


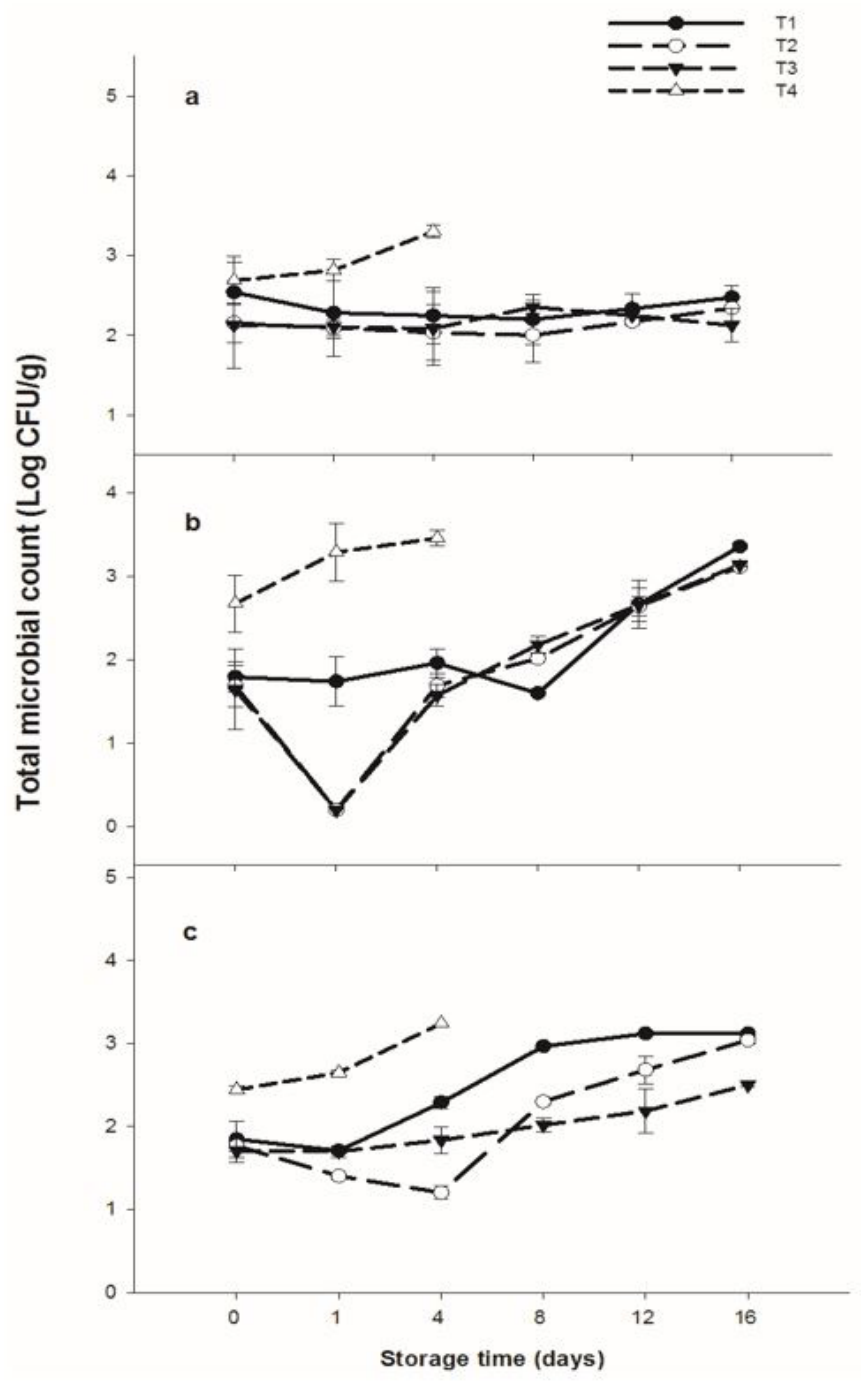

Figure 3. Effects of chitosan-tomato plant extract coatings on the total aerobic mesophilic (a), total coliform (b) and psychrophilic bacteria (c) in chicken during refrigerated storage.

to the addition of antimicrobial compounds that improve the preservation of the meat products.

\subsection{Antioxidant capacity}

The T2 treatment produced better ABTS (Figure 4a) and DPPH (Figure $4 \mathrm{~b}$ ) results, with values of 0.440 and $0.387 \mathrm{mmol} \mathrm{TE} / \mathrm{g}$ of meat, respectively. Huang et al. (2011) reported similar antioxidant capacities in fresh and cooked mutton and pork treated with Nelumbo nucifera root and leaf extracts. The antioxidant capacity of the treated meat was significantly higher than that of the control (T4).

The T3 treatment had a higher TPC content with an initial value of $29 \mathrm{mg} \mathrm{GAE} / \mathrm{g}$ of meat and a final value of $21 \mathrm{mg} \mathrm{GAE} / \mathrm{g}$ of meat, followed by T2 and T1 (Figure 5). A significant difference $(\mathrm{p}<0.05)$ was observed between treatments with edible coatings with or without tomato extracts and the control; the behavior was

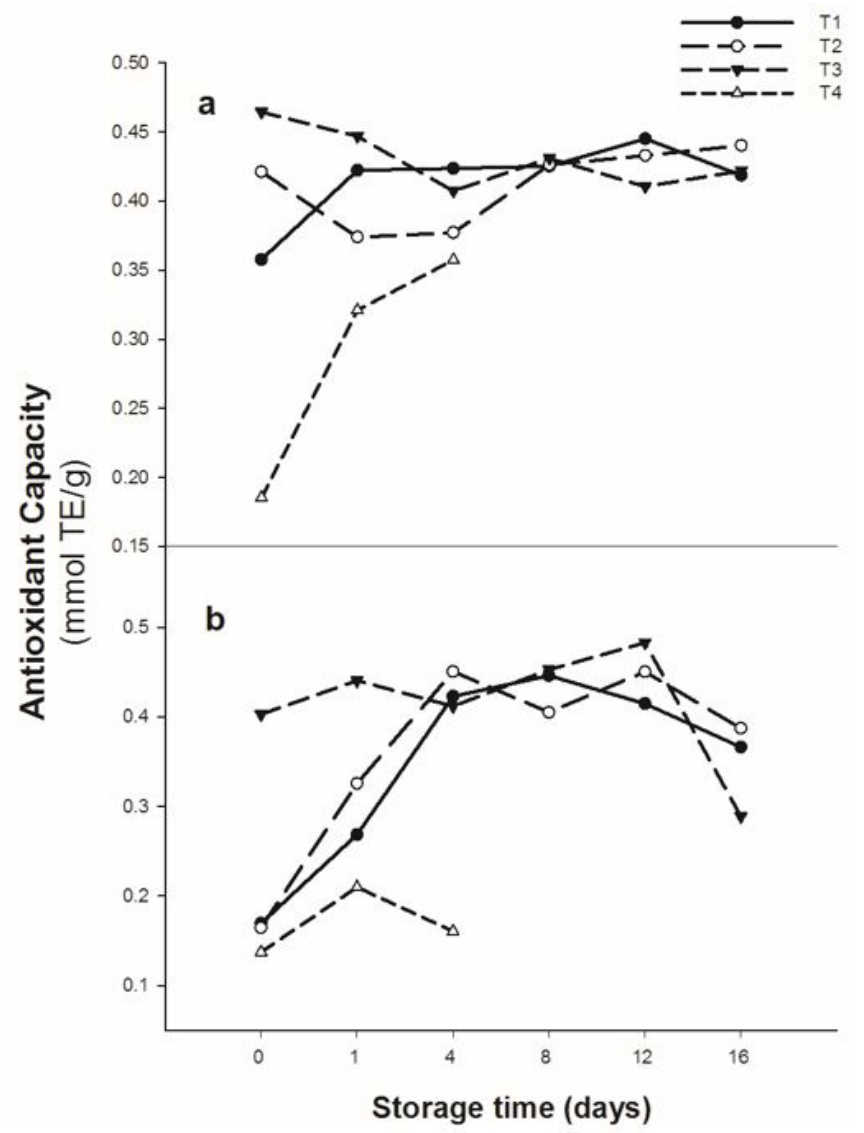

Figure 4. Effects of chitosan-tomato plant extract on the antioxidant capacity evaluated by the ABTS (a) and DPPH (b) methods in chicken during refrigerated storage.

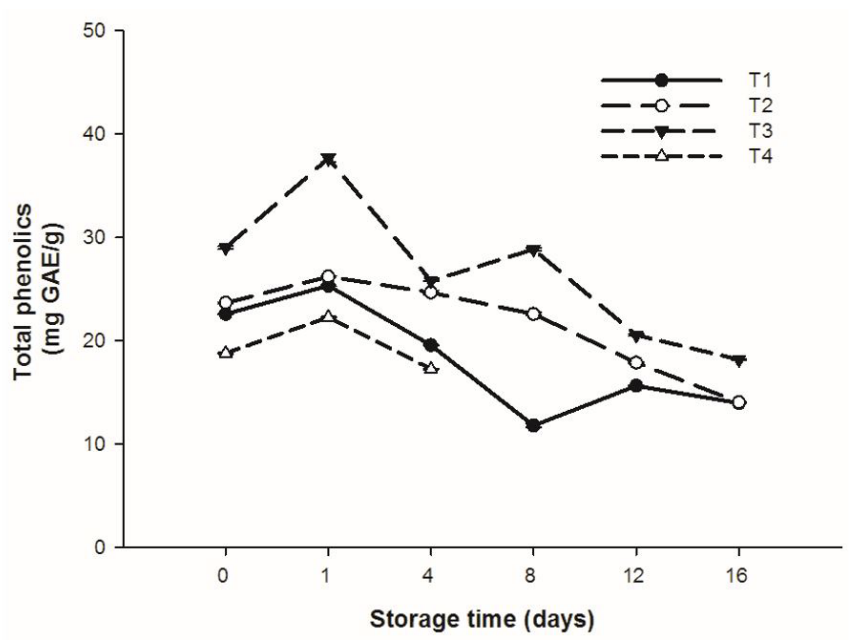

Figure 5. Effects of chitosan-tomato plant extract on the total phenolics in chicken during refrigerated storage.

variable during the storage period. Some studies have evaluated the antioxidant capacity and the total phenolic compounds in extracts used in meat preservation (Lahucky et al., 2010; Chang et al., 2011; Huang et al., 2011; Biswas et al., 2012) with edible coatings; however, analyses of the different treatments 
with extracts were not shown. The authors related the higher antioxidant capacity of the treatments to their TPC, which enables the treatments to decrease the principal deterioration problems.

\section{Conclusions}

Therefore, chitosan-based edible coatings with tomato plant extract added can be used to increase the shelf life while maintaining some of the quality parameters and improve the microbial safety of chicken during refrigerated storage.

\section{Acknowledgements}

The authors acknowledge the financial support from the Instituto Tecnológico de Sonora (project PROFAPI 00500 and 2017-0049) and PFCE.

\section{References}

Ahmed, N., Dora, K. C., Chowdhury, S., Sarkar, S., \& Mishra, R. (2017). Effect of chitosan and acetic acid on the shelf life of sea bass fillets stored at refrigerated temperatura. Journal of Applied and Natural Science, 9(4), 2175-2181. http://dx.doi.org/10.31018/jans.v9i4.1506.

Association of Official Analytical Chemists - AOAC. (1995). Official methods of analysis. Gaithersburg: AOAC.

Bertram, H. C., Andersen, H. J., Karlsson, A. H., Horn, P., Hedegaard, J., Norgaard, L., \& Engelsen, S. B. (2003). Prediction of technological quality (cooking loss and Napole Yield) of pork based on fresh meat characteristics. Meat Science, 65(2), 707-712. http://dx.doi. org/10.1016/S0309-1740(02)00272-3. PMid:22063431.

Biswas, A. K., Chatli, M. K., \& Sahoo, J. (2012). Antioxidant potential of curry (Murraya koenigii L.) and mint (Mentha spicata) leaf extracts and their effect on colour and oxidative stability of raw ground pork meat during refrigeration storage. Food Chemistry, 133(2), 467-472. http://dx.doi.org/10.1016/j.foodchem.2012.01.073. PMid:25683421.

Boziaris, I. S., Kordila, A., \& Neofitou, C. (2011). Microbial spoilage analysis and its effect on chemical changes and shelf-life of Norway lobster (Nephrops norvegicus) stored in air at various temperatures. International Journal of Food Science \& Technology, 46(4), 887-895. http://dx.doi.org/10.1111/j.1365-2621.2011.02568.x.

Cao, Y., Gu, W., Zhang, J., Chu, Y., Ye, X., Hu, Y., \& Chen, J. (2013). Effects of chitosan, aqueous extract of ginger, onion and garlic on quality and shelf life of stewed-pork during refrigerated storage. Food Chemistry, 141(3), 1655-1660. http://dx.doi.org/10.1016/j. foodchem.2013.04.084. PMid:23870874.

Chang, H. L., Chen, Y. C., \& Tan, F. J. (2011). Antioxidative properties of a chitosan-glucose Maillard reaction product and its effect on pork qualities during refrigerated storage. Food Chemistry, 124(2), 589-595. http://dx.doi.org/10.1016/j.foodchem.2010.06.080. PMid:23140704.

Erel, O. (2004). A novel automated direct measurement method for total antioxidant capacity using a new generation, more stable ABTS radical cation. Clinical Biochemistry, 37(4), 277-285. http://dx.doi. org/10.1016/j.clinbiochem.2003.11.015. PMid:15003729.

Fernández-Pan, I., Carrión-Granda, X., \& Maté, J. I. (2014). Antimicrobial efficiency of edible coatings on the preservation of chicken breast fillets. Food Control, 36(1), 69-75. http://dx.doi.org/10.1016/j. foodcont.2013.07.032.

Higueras, L., López-Carballo, G., Hernández-Muñoz, P., Gavara, R., \& Rollini, M. (2013). Development of a novel antimicrobial film based on chitosan with LAE (ethyl-Na-dodecanoyl-L-arginate) and its application to fresh chicken. International Journal of
Food Microbiology, 165(3), 339-345. http://dx.doi.org/10.1016/j. ijfoodmicro.2013.06.003. PMid:23816804.

Huang, B., He, J., Ban, X., Zeng, H., Yao, X., \& Wang, Y. (2011). Antioxidant activity of bovine and porcine meat treated with extracts from edible lotus (Nelumbo nucifera) rhizome knot and leaf. Meat Science, 87(1), 46-53. http://dx.doi.org/10.1016/j.meatsci.2010.09.001. PMid:20869815.

Huang, L., Zhao, J., Chen, Q., \& Zhang, Y. (2014). Nondestructive measurement of total volatile basic nitrogen (TVB-N) in pork meat by integrating near infrared spectroscopy, computer vision and electronic nose techniques. Food Chemistry, 145(1), 228-236. http://dx.doi.org/10.1016/j.foodchem.2013.06.073. PMid:24128472.

Huang, W., Xu, H., Xue, Y., Huang, R., Deng, H., \& Pan, S. (2012). Layer-by-layer inmobilization of lysozyme-chitosan-organic rectorite composites on electrospun nanofibrous mats of pork preservation. Food Research International, 48(2), 784-791. http:// dx.doi.org/10.1016/j.foodres.2012.06.026.

Kapetanakou, A. E., Agathaggelou, E. I., \& Skandamis, P. N. (2014). Storage of pork meat under modified atmospheres containing vapors from commercial alcoholic beverages. International Journal of Food Microbiology, 178(1), 65-75. http://dx.doi.org/10.1016/j. ijfoodmicro.2014.02.021. PMid:24667319.

Khanafari, A., Marandi, R., \& Sanaeti, S. (2008). Recovery of chitin and chitosan from shrimp waste by chemical and microbial methods. Iranian Journal of Environmental Health Sciences \& Engineering, 5(1), 19-24. Retrieved from http://ijehse.tums.ac.ir/index.php/ ijehse/article/download/145/144

Kiliç, B., Şimşek, A., Claus, J. R., \& Atilgan, E. (2014). Encapsulated phosphates reduce lipid oxidation in both ground chicken and ground beef during raw and cooked meat storage with some influence on color, $\mathrm{pH}$, and cooking loss. Meat Science, 97(1), 93-103. http:// dx.doi.org/10.1016/j.meatsci.2014.01.014. PMid:24553491.

Kristensen, L., \& Purslow, P. P. (2001). The effect of ageing on the waterholding capacity of pork: role of cytoeskeletal proteins. Meat Science, 58(1), 17-23. http://dx.doi.org/10.1016/S0309-1740(00)00125-X. PMid:22061914.

Lahucky, R., Nuernberg, K., Kovac, L., Bucko, O., \& Nuernberg, G. (2010). Assessment of the antioxidant potential of selected plant extracts - In vitro and in vivo experiments on pork. Meat Science, 85(4), 779-784. http://dx.doi.org/10.1016/j.meatsci.2010.04.004. PMid:20488625.

Latou, E., Mexis, S. F., Badeka, A. V., Kontakos, S., \& Kontominas, M. G. (2014). Combined effect of chitosan and modified atmosphere packaging for shelf life extension of chicken breast fillets. LebensmittelWissenschaft + Technologie, 55(1), 263-268. http://dx.doi.org/10.1016/j. lwt.2013.09.010.

López-Mata, M. A., Ruiz-Cruz, S., Ornelas-Paz, J. J., Cira-Chávez, L. A., \& Silva-Beltrán, N. P. (2015). Antibacterial and antioxidant properties of edible chitosan coatings incorporated with essential oils. International Journal o Pharma Bio Sciences, 6(4), 251-264. Retrieved from http://www.ijpbs.net/cms/php/upload/4597_pdf.pdf

López-Mata, M. A., Ruíz-Cruz, S., Silva-Beltrán, N. P., Ornelas-Paz, J. J., Zamudio-Flores, P. B., \& Burruel-Ibarra, S. E. (2013). Physicochemical, antimicrobial and antioxidant properties of chitosan films incorporated with carvacrol. Molecules (Basel, Switzerland), 18(11), 13735-13753. http://dx.doi.org/10.3390/molecules181113735. PMid:24213653.

MacDougall, D. B. (1982). Changes in the colour and opacity of meat. Food Chemistry, 9(1-2), 75-88. http://dx.doi.org/10.1016/03088146(82)90070-x.

Mantilla, S. P. S., Santos, É. B. H., Vital, D. C., Mano, S. B., Freitas, M. Q. D., \& Franco, R. M. (2011). Microbiology, sensory evaluation and 
shelf life of irradiated chicken breast fillets stored in air or vacuum. Brazilian Archives of Biology and Technology, 54(3), 569-576. http:// dx.doi.org/10.1590/S1516-89132011000300019.

Márquez-Ríos, E., Castillo-Yañez, F. J., Graciano-Verdugo, A. Z., Jiménez-Ruíz, E. I., Lugo-Sánchez, M. E., Maeda-Martínez, A. N., \& Ocaño-Higuera, V. M. (2011). Impacto de las prácticas artesanales de captura y manejo postcaptura en la calidad del músculo de cazón. Interciencia, 36(9), 672-676. Retrieved from http://www.redalyc.org/ articulo.oa? $\mathrm{id}=33921204006$

México. Secretaria de Salud. (1994a). Norma Oficial Mexicana NOM092-SSA1-1994. Bienes y servicios. Método para la cuenta de bacterias aerobias en placa. Diario Oficial de la Federación. Retrieved from http://www.salud.gob.mx/unidades/cdi/nom/092ssa14.html

México. Secretaria de Salud. (1994b). Norma Oficial Mexicana NOM-113SSA1-1994. Bienes y servicios. Método para la cuenta de organismos coliformes totales en placa. Diario Oficial de la Federación. Retrieved from http://www.salud.gob.mx/unidades/cdi/nom/112ssa14.html

Mirabella, N., Castellani, V., \& Sala, S. (2014). Current options for the valorization of food manufacturing waste: a review. Journal of Cleaner Production, 65(1), 28-41. http://dx.doi.org/10.1016/j. jclepro.2013.10.051.

Olaimat, A. N., \& Holley, R. A. (2015). Control of Salmonella on fresh chicken breasts by k-carrageenan/chitosan-based coatings containing allyl isothiocyanate or deodorized Oriental mustard extract plus EDTA. Food Microbiology, 48, 83-88. http://dx.doi.org/10.1016/j. fm.2014.11.019. PMid:25790995.

Petrou, S., Tsiraki, M., Giatrakou, V., \& Savvaidis, I. N. (2012). Chitosan dipping or oregano oil treatments, singly or combined on modified atmosphere packaged chicken breast meat. International Journal of Food Microbiology, 156(3), 264-271. http://dx.doi.org/10.1016/j. ijfoodmicro.2012.04.002. PMid:22534355.

Qi, S., Huang, H., Huang, J., Wang, Q., \& Wei, Q. (2015). Lychee (Litchi sinensis Sonn.) seed water extract as potential antioxidant and antiobese natural additive in meat products. Food Control, 50, 195-201. http://dx.doi.org/10.1016/j.foodcont.2014.08.047.

Qin, H., Xu, P., Zhou, C., \& Wang, Y. (2015). Effects of L-Arginine on water holding capacity and texture of heat-induced gel of salt-soluble proteins from breast muscle. Lebensmittel-Wissenschaft + Technologie, 63(2), 912-918. http://dx.doi.org/10.1016/j.lwt.2015.04.048.

Qin, Y., Yang, J., Lu, H., Wang, S., Yang, J., Yang, X., Chai, M., Li, L., \& Cao, J. (2013). Effect of chitosan film incorporated with tea polyphenol on quality and shelf life of pork meat patties. International Journal of Biological Macromolecules, 61(1), 312-316. http://dx.doi. org/10.1016/j.ijbiomac.2013.07.018. PMid:23916647.

Qwele, K., Hugo, A., Oyedemi, S. O., Moyo, B., Masika, P. J., \& Muchenje, V. (2013). Chemical composition, fatty acid content and antioxidant potential of meat from goats supplemented with Moringa (Moringa oleifera) leaves, sunflower cake and grass hay. Meat Science, 93(3), 455462. http://dx.doi.org/10.1016/j.meatsci.2012.11.009. PMid:23273450.

Radha-Krishnan, K., Babuskin, S., Azhagu Saravana Babu, P., Sasikala, M., Sabina, K., Archana, G., Sivarajan, M., \& Sukumar, M. (2014).
Antimicrobial and antioxidant effects of spice extracts on the shelf life extension of raw chicken meat. International Journal of Food Microbiology, 171, 32-40. http://dx.doi.org/10.1016/j. ijfoodmicro.2013.11.011. PMid:24308943.

Rodríguez-Calleja, J. M., Cruz-Romero, M. C., O’Sullivan, M. G., García-López, M. L., \& Kerry, J. P. (2012). High-pressure-based hurdle strategy to extend the shelf-life of fresh chicken breast fillets. Food Control, 25(2), 516-524. http://dx.doi.org/10.1016/j. foodcont.2011.11.014.

Sánchez-Ortega, I., García-Almendárez, B. E., Santos-López, E. M., Amaro-Reyes, A., Barboza-Corona, J. E., \& Regalado, C. (2014). Antimicrobial edible films and coatings for meat and meat products preservation. The Scientific World Journal, 2014(1), 1-18. http:// dx.doi.org/10.1155/2014/248935. PMid:25050387.

Selani, M. M., Contreras-Castillo, C. J., Shirahigue, L. D., Gallo, C. R., Plata-Oviedo, M., \& Montes-Villanueva, N. D. (2011). Wine industry residues extracts as natural antioxidants in raw and cooked chicken meat during frozen storage. Meat Science, 88(3), 397-403. http://dx.doi.org/10.1016/j.meatsci.2011.01.017. PMid:21342750.

Silva-Beltrán, N. P., Ruiz-Cruz, S., Cira-Chávez, L. A., Estrada-Alvarado, M. I., Ornelas-Paz, J. J., López-Mata, M. A., Del-Toro-Sánchez, C. L., Ayala-Zavala, J. F., \& Márquez-Ríos, E. (2015). Total phenolic, flavonoid, tomatine and tomatidine contents and antioxidant and antimicrobial activities of extracts of tomato plant. International Journal of Analytical Chemistry. 2015, 1-10. http://dx.doi. org/10.1155/2015/274071.

Soultos, N., Tzikas, Z., Abrahim, A., Georgantelis, D., \& Ambrosiadis, I. (2008). Chitosan effects on quality properties of Greek style of fresh pork sausages. Meat Science, 80(4), 1150-1156. http://dx.doi. org/10.1016/j.meatsci.2008.05.008. PMid:22063850.

Soysal, Ç., Bozkurt, H., Dirican, E., Güçlü, M., Bozhüyük, E. D., Uslu, A. E., \& Kaya, S. (2015). Effect of antimicrobial packaging on physicochemical and microbial quality of chicken drumsticks. Food Control, 54, 294-299. http://dx.doi.org/10.1016/j.foodcont.2015.02.009.

Suseno, N., Savitri, E., Sapei, L., \& Padmawijaya, K. S. (2014). Improving shelf-life of cavendish banana using chitosan edible coating. Procedia Chemistry, 9(1), 113-120. http://dx.doi.org/10.1016/j. proche.2014.05.014.

$\mathrm{Wu}, \mathrm{S}$. (2014). Effect of chitosan-based edible coating on preservation of white shrimp during partially frozen storage. International Journal of Biological Macromolecules, 65(1), 325-328. http://dx.doi. org/10.1016/j.ijbiomac.2014.01.056. PMid:24491494.

Young, J. F., Karlsson, A. H., \& Henckel, P. (2004). Water-holding capacity in chicken breast muscle is enhanced by pyruvate and reduced by creatine supplements. Poultry Science, 83(3), 400-405. http://dx.doi. org/10.1093/ps/83.3.400. PMid:15049492.

Zhang, M., Mittal, G. S., \& Barbut, S. (1995). Effects of tests conditions on the water holding capacity of meat by a centrifugal method. Lebensmittel-Wissenschaft + Technologie, 28(1), 50-55. http://dx.doi. org/10.1016/S0023-6438(95)80012-3. 